\title{
A teoria literária aristofânica
}

\author{
MARCOS MARTINHO DOS SANTOS \\ Departamento de Letras Clássicas e Vernáculas \\ Faculdade de Filosofia, Letras e Ciências Humanas \\ Universidade de São Paulo
}

\begin{abstract}
RESUMO: A par do tema sócio-político, figura, na comédia aristofânica, o tema literário. Desenvolve-se este, de maneira esporádica, numa cena dos Acarnenses (407-78) e, de maneira incontingente, nas Mulheres que celebram as Tesmofórias - em especial na cena em que aparece Agatão (Thesm. 97-265) - e na segunda parte das Rãs (738-1533). Pode-se dizer que a comédia aristofânica elabora um sistema de critica literária, em que se distinguem dois tipos fundamentais de poesia: a poesia que imita a própria poesiá (tékhne), cujo modelo é Eurípides, e a poesia que imita a natureza (phýsis), cujo modelo é Ésquilo.
\end{abstract}

PALAVRAS-CHAVE: Aristofanes, teoria literária, teatro.

\section{Poesia e técnica}

Diz Agatão, no prólogo das Mulheres que celebram as Tesmofórias, que a poesia é reflexo da natureza do poeta (Thesm. 167), de modo que, como ele mesmo exemplifica, se um poeta é belo e se veste bem, os poemas que este compuser serão igualmente belos (Thesm. 164-6), e assim por diante (cf. Thesm. 160-3, 168-70; Ach. 138-40). Essa relaçāo entre a natureza e a obra do poeta é, todavia, fruto da "necessidade" (cf. Thesm. 167: anánke, 171: anánke). Porém, um poeta pode querer fazer poesia distinta de sua natureza. Isso não é impossível, contanto que ele recorra a um mecanismo que lhe permita escapar à necessidade. Ora, esse mecanismo é a técnica mimética, ou, simplesmente, mimese (Thesm. 156: mimesis) ${ }^{1}$.

A mimese permite ao poeta elaborar uma poesia que nāo reflita a natureza do próprio poeta (cf. Thesm. 155-6). Essa dissociação entre a natureza do poeta e a representação poética é pressentida, ainda no prólogo das Mulheres que celebram as Tesmoforias, pelo parente torto de Eurípides, que não sabe se realmente deve analisar a natureza do. poeta Agatão pelas composiçōes corais deste (Thesm. 144-5).

O procedimento a que recorre o poeta é o de participar artificialmente de uma natureza alheia à.sua e, então, construir a representação poética. Assim como, 
nos Acamenses, Eurípides fica de pernas para o ar (Ach. 399-400, 410) para elaborar personagens de coxos (Ach. 411), se veste com farrapos (Ach. 412-3) para elaborar personagens de mendigos (Ach. 413), assim, em Thesm. 136-43, Agatāo, para elaborar personagens femininas (Thesm. 151), se veste de mulher, chegando a confundir, por sua figura andrógina, o parente torto de Eurípides (Thesm. 97-8, 143).

Desse modo, porém, a poesia, que seria a representação da natureza, passa a ser a representação da representaçāo da natureza. À realidade empírica, que serviria de base para a representação poética, substitui-se a própria representação. Assim, não é necessário ser, por exemplo, um homem virtuoso para poder representar o caráter virtuoso; na verdade, nem é preciso, não sendo homem virtuoso, imitar a própria virtude de outrem. $O$ que é preciso imitar é aquilo que, no próprio homem virtuoso, já é representação do caráter do mesmo. O que seja mais precisamente essa representação da representação ensina-nos um passo do prólogo da Assembléia das mulheres, em que Praxágora tenta ensinar suas companheiras a representar a figura masculina. Ora, os apontamentos daquela chamam a atenção não exatamente para a maneira de ser (natureza), mas para a maneira de falar (representação da natureza) dos homens:

\section{Áge nŷn hópos andristi kai kalôs ereîs (Eccl. 149)}

Vai! Agora discursarás à maneira dos homens e belamente.

Praxágora chama a atençāo das companheiras para os hábitos lingüísticos dos homens. Por exemplo, a interpelação das duas deusas é um hábito lingüístico das mulheres (Eccl. 156-8; cf. 189-91); os homens invocam Zeus (Eccl. 158, 213) ou Apolo (Eccl. 160). Cuida Praxágora para que suas companheiras não se deixem trair pelas palavras (Eccl. 165-6).

Assim, é a palavra que reflete, ou representa, a natureza da pessoa, e, conseqüentemente, a técnica mimética, representação da representação, deve, ao modelar uma personagem, fazer que o discurso desta seja a representação do discurso da pessoa.

O citado passo da Assembléia das mulheres assemelha-se, pela ação, aos versos 213-68 do prólogo das Mulheres que celebram as Tesmoforias: lá, Praxágora quer preparar mulheres para falar a favor das mulheres na Assembléia, perante os homens; aqui, Eurípides prepara seu parente torto para infiltrar-se na celebração das Tesmofórias e, às mulheres, falar contra as mulheres. Ora, assim como Praxágora se preocupa com a representação do discurso, no caso o dos homens - ela própria será a escolhida para falar em nome das mulheres após demonstrar sua habilidade em imitar o discurso masculino (Eccl. 171-240) -, assim Eurípides, no momento em que seu parente torto vai partir para sua missāo, lembra este de falar, mais exatamente "tagarelar" (laléo) como mulher:

\section{[...] En lalês d', hopos tô phthégmati} gynaikeîs ea [...] (Thesm. 267-8)

Se falas, faze-o de modo a afeminares bem a linguagem.

Mas tanto Eurípides quanto Praxágora elaboram mais propriamente oradores, não personagens dramáticas. Em outras palavras, a mimese pode ser tanto técnica poética, como o demonstrou Agatão, quanto técnica retórica. Como confessa Praxágora, seu conhecimento da arte de discursar provém dos oradores (Eccl. 
244). E outra personagem feminina das Mulheres que celebram as Tesmofórias, hábil no manejo do discurso (Thesm. 436), conhece não só as fórmulas da oratória (cf. Thesm. 432), mas até mesmo os tiqués dos oradores (cf. Thesm. 381-2).

Porém, seja técnica poética seja técnica retórica, ambas são técnicas da palavra; a técnica poética constrói suas personagens por meio do discurso, tal qual a retórica modela o eu do orador por meio do discurso. Assim, é característico de Agatão o cuidado minucioso com a estrutura lingüística, ou "carcaça do drama" (Thesm. 52: dryókhous drámatos; cf. Thesm. 52-7). Quanto a Eurípides, foi ele quem ensinou aos homens medir o verso com o esquadro, aplicando a este regras sutis (Ran. 956), e seu estilo é, por isso, "elegante" (Thesm. 93) ${ }^{2}$.

Curiosamente, porém, a primeira personagem feminina do agón das Mulheres que celebram as Tesmofórias, a que demonstrou conhecer os artifícios retóricos do discurso (Thesm. 381-2, 432), perdeu o duelo (Thesm. 459-61). E por que, senão justamente por ter demonstrado conhecer aqueles recursos, ou melhor, por ter deixado o ouvinte, no caso o coro, perceber a manipulação retórica do discurso (Thesm. 381-2)?

Pois as técnicas poética e retórica, embora manipulem o discurso com meticulosidade, não devem permitir que a mesma manipulação transpareça aos olhos do espectador ${ }^{3}$. O estilo euripidiano evita ao máximo o choque entre espectador e forma. A linguagem de Eurípides, embora toda manipulada, é simples ${ }^{4}$ (Ran. 961-2, 939-43), e não só a linguagem, mas toda a estrutura dramática, que sempre, quase didadicamente, apresenta, na voz da primeira personagem a entrar no palco, toda a origem da ação dramática ${ }^{5}$ (Ran. 946-7). O teatro de Eurípides é elaborado com o objetivo de tornar-se perfeitamente compreensível ao espectador. Em Ran. $1434^{6}$, o advérbio saphôs associa-se a Eurípides, e o hemistíquio euripidiano citado em Ran. 64 faz uma paródia da preocupação do teatro de Eurípides com a "clareza" do discurso":

\section{Âr'ekdidásko tò saphès è péra phráso;}

E então? Demonstro com clareza ou explicarei ainda mais?

Por outro lado, Eurípides critica o estilo de Esquilo justamente pela "falta de clareza" (Ran. 927), por ser ininteligível para o espectador (Ran. 926),-devido aos excessos da linguagem (Ran. 922-5), que mais parece um hieróglifo (Ran. 928-32; cf. Ran. 937-8). Assim, se Eurípides evita a percepção metalingüística do espectador, o estilo de Esquilo fá-la vibrar. Em Ran. 930-2, ironiza-se essa "falha" do teatro esquilino, a dizer Dioniso que ficou a noite toda pensando no significado de determinada palavra empregada numa tragédia de Esquilo ${ }^{8} .$.

Mas o que exatamente pretende Eurípides ao cuidar da clareza de suas composições? Ora, essa mesma clareza permite ao espectador penetrar o teatro euripidiano - a linguagem e a estrutura dramática - com tal facilidade que aquele nem percebe ter diante de si uma forma poética, quer dizer, nāo pensa estar olhando para uma representação poética (técnica mimética), mas se sente diante da própria realidade (natureza); enfim, é realismo o que pretende Eurípides. Por isso o argumento que o tragediógrafo lança, no agón das $R a \tilde{s}$, contra a crítica de Ésquilo ao teatro euripidiano (Ran. 1043-4, 1050-1) alega justamente a força de realismo deste teatro (Ran. 1052), efeito poético impraticável para o teatro do seu contendor, em cuja linguagem tem de reparar a todo instante o espectador. 
Mas se o teatro euripidiano é obra da técnica mimética, isto é, um discurso que imita um discurso, qual o exato tipo de discurso que deve imitar? Ora, uma vez que pretende ser claro e realista, o que consegue não deixando transparecer os recursos técnicos empregados na construção de sua poesia, a que outro discurso aplicará sua técnica mimética, senāo àquele que por natureza nāo é elaborado? Em outras palavras, deve imitar a fala descuidada do povo, e o tipo mais informal desta: a fala dos comerciantes, a fala da ágora (cf. supra notas 4 e 8). Em termos técnicos, Eurípides teria aliviado a tragédia da linguagem rebuscada (Ran. 939-40, 961), conferindo-lhe uma forma mais enxuta (Ran. 941-2); teria elaborado um estilo de tom pedestre, mais apto a representar o discurso cotidiano dos homens da agora $^{9}$ (cf. Ran. 1015) que o estilo preciosista (Ran. 836-9) e empolado (Ran. $839,961)$ de Ésquilo.

Mas se tal é o estilo, seria difícil, pela lei da verossimilhança, que as personagens do teatro de Eurípides representassem grandes heróis. E certo que uma tragédia deva apresentar heróis, mas os de Eurípides são todos deformados. Deformados fisicamente, como o cego Fênix (Ach. 421), o coxo Belerofonte (Ach. 427), os feridos e esfarrapados Filoctetes (Ach. 424) e Télefo (Ach. 430); deformados moralmente, como as adúlteras e incestuosas (Thesm. 392-4; Ran. 850, 1044, 1079-81) Melanipas, Fedras e Estenebéias (Thesm. 547; Ran. 1043). Ora, que são essas personagens senão figuras que mais bem retratam a realidade empírica que heróis fortes e virtuosos, como os Pátroclos e Teucros de Esquilo (cf. Ran. 1042)? Enfim, apenas atenção à verossimilhança, isto é, observação da conformidade entre o discurso e o caráter da personagem dramática, procedimento tảo caro à técnica poética ${ }^{10}$.

E não somente as personagens são elaboradas em conformidade com o discurso, mas também a ação. $O$ próprio Eurípides explica que o realismo de seu teatro se deve ao cuidado de se elaborarem imagens que reproduzam cenas cotidianas da vida dos homens (Rani. 959-61). Enfim, o realismo do discurso euripidiano estende-se, pela atenção à verossimilhança, às personagens e à própria ação dramática.

Mas trata-se sempre de representação poética, isto é, se o discurso do comerciante é por natureza descuidado, o da personagem euripidiana é descuidado por imitação. Ao mesmo tempo, porém, graças ao efeito de realismo produzido pelo discurso poético e garantido pela lei da verossimilhança, que ajusta o caráter e a ação da personagem dramática ao discurso, a mimese, representação da representação do ser (técnica), produz no espectador a sensação do ser (natureza).

O realismo é um efeito estético (técnica mimética), diferente, portanto, da realidade, uma verdade empírica (natureza); mas a mimese faz o espectador tomar aquela por esta. Numa palavra, a mimese produz ilusão no espectador. Eurípides, tão logo modelada, no prólogo das Mulheres que celebram as Tesmofórias, a figura feminina que seu parente torto representará, observa que a mesma não passa de "aparência" de figura feminina (cf. Thesm. 266-7: eîdos). O tragediógrafo conhece perfeitamente a natureza "ilusória" da poesia, de que fala no início do epirrema do agón das Rãs (910: exepáta; cf. Eccl. 237-8: exapatetheís e exapatán).

Observe-se ainda que o discurso realista deve; a fim de parecer informal, causar a impressão de não ter sido preparado; vale dizer, deve imitar (técnica mimética) a improvisaçāo espontânea (natureza) da linguagem empregada na ágora. Para o coro das Mulheres que celebram as Tesmofórias, venceu o agón o discurso da segunda personagem feminina, o que pareceu "nāo ter sido premeditado" (Thesm. 462: ouk ákaira). A explicação é simples. Se, pela lei da verossimilhança, 
se exigem, para um discurso realista, personagens e ação dramática realista, para um discurso improvisado, espera-se uma personagem espontânea, ou ainda, sincera.

Como o realismo, a sinceridade é mais um efeito ilusório da técnica poética. O discurso, por meio da lei da verossimilhança, produz a expectativa de sinceridade da personagem (efeito mimético), mas essa expectativa confunde-se, no espectador, com a própria sinceridade (natureza).

Da ilusão de sinceridade, porém, decorre ainda outro efeito. Pois o espectador, já iludido pela aparência de realidade, agora sente simpatia pelo discurso que ouve; em outras palavras, se o discurso é, ou melhor, parece sincero, o espectador sentirá confiança nele. Assim, se a primeira personagem feminina do agón das Mulheres que celebram as Tesmofórias falou de maneira imparcial (cf. Thesm. 383) e por meio de argumentos (Thesm. 437), com certeza o coro reconhecerá a justiça do discurso daquela, mas não se comoverá com ele, porque percebeu a frieza do mesmo, todo sopesado pela perspicácia da oradora (Thesm. 439). A segunda personagem feminina, contudo, por falar de maneira parcial (Thesm. 445) e por meio de imagens apelativas (Thesm. 446-52), demonstra que o seu discurso é descontrolado pela emoção. Este, sim, angariará toda a simpatia do coro (Thesm. 459-65), que julgará o discurso "convincente" (Thesm. 464: pithaná) ${ }^{11}$.

Tráta-se do efeito da persuasāo do ouvinte, efeito precioso para a técnica retórica. Que é isso o que o teatro de Eurípides produz no espectador provam as palavras do coro que comentam o discurso daquela segunda personagem feminina: primeiro, qualifica-se este com o adjetivo kompsós (Thesm. 460), que bem se associa ao estilo euripidiano (cf. supra nota 2); segundo, e mais importante, atribui-se o poder de persuasão do discurso à "inteligibilidade" do mesmo (Thesm. 463-4), que corresponde à qualidade fundamental de clareza do estilo euripidiano. No prólogo das Mulheres que celebram as Tesmofórias, o próprio Eurípides recomenda a seu parente torto, na figura da personagem feminina construída pelo poeta, falar "com persuasão" (Thesm. 268: pithanôs). Também a Eurípides lança o coro, no êxodo da mesma comédia, o desafio de "persuadir" o arqueiro bárbaro (Thesm. 1171: peîthe).

Pela lei da verossimilhança, se o discurso aparenta sincero, produz no espectador ou ouvinte a expectativa de também ser o que o profere sincero, e esse efeito da técnica mimética será confundido com a natureza do imitador; em outras palavras, o espectador ou ouvinte julgará realmente sincero o que profere aquele discurso. Logo a persuasāo repousa unicamente na forma do discurso, isto é, na clareza e aparente informalidade deste, e nas leis intrínsecas do discurso (as leis da verossimilhança). A citação da Antígona de Eurípides em Ran. 1391 proclama a ascendência da palavra na produção da persuasão ${ }^{12}$ :

\section{Ouk ésti Peithoûs hieròn állo plèn Lógos}

Não existe outro templo da Persuasão além da Palavra.

Assim, ao efeito poético de realismo, sobrepõe-se o de sinceridade, que, por sua vez, produz o efeito retórico da persuasão do espectador ou ouvinte. De outros procedimentos retóricos pode valer-se agora a técnica mimética. Pode, por exemplo, intensificar a força da persuasão procurando, mais que conquistar a confiança, excitar a piedade do espectador ou ouvinte. Elabora-se, então, uma personagem ou um orador apto a produzir tal efeito. Pode-se representar uma figura tirada diretamente do cotidiano, como a segunda personagem feminina das 
Mulheres que celebram as Tesmoforias, uma simples vendedora de flores (Thesm. 447-8), apta a excitar a piedade do espectador por sua singeleza natural.

No caso de Eurípides, um tragediógrafo, o emprego desse efeito pode causar algum embaraço, pois a tragédia deve, por sua particularidade formal, nutrir-se de figuras mais nobres, que dificilmente excitariam a piedade do espectador. Assim, a solução euripidiana, como já vimos, é apresentar figuras que, se bem que heróicas, sejam deformadas ${ }^{13}$. Diceópolis procura Eurípides porque pretende excitar a "piedade" do coro (Ach. 383-4, 436: athliótaton) $)^{14}$, e Eurípides, por sua vez, esmera-se em modelar personagens que produzam tal efeito, justamente as personagens de coxos e mendigos (Ach. 410-3; cf. Pac. 147-8, 740; Ran. 842, 1063-4). Em $A c h$. 418-31 faz-se uma hilariante paródia desse recurso composicional de Eurípides. E como se este pensasse: "Uma figura desgraçada? Sim, esta! Ou não, talvez seja melhor esta outra, mais desgraçada. Também não, mas esta terceira, ainda mais desgraçada!"...

Trata-se do efeito retórico convencionalmente chamado captatio beneuolentiae, que intensifica o efeito retórico de persuasão do espectador ou ouvinte.

Assim, a técnica mimética abdica da realidade, uma vez que é representação da representação, discurso que imita discurso. Com o simples manuseio do discurso, produz no espectador ou ouvinte a sensação de realismo e confiança, isto é, constrói o realismo (efeito poético) e recusa a realidade (natureza), produz a persuasāo (efeito retórico) e rejeita a sinceridade (natureza). Mas isso não é tudo. A técnica mimética não só abdica da natureza, mas também a compromete, pois, ainda que um orador possuísse um caráter (natureza), isso de nada lhe valeria, se não soubesse representá-lo retoricamente (técnica mimética). Em outras palavras, a confiança do ouvinte, trabalhada por um jogo persuasivo puramente lingüístico, não seria conquistada, e o próprio discurso, se mal formulado, comprometeria a natureza do orador. Vale dizer, não basta ao orador "ser (por natureza)", é necessário "parecer ser (por imitação)". Vão de encontro a essas palavras as do Télefo de Eurípides, citado em Ach. 440-1:

\section{Dề gár me dóxai ptokhón eînai témeron,} eînai mèn hósper eiml, phaínesthai dè mé

Necessito, pois, apresentar-me hoje como mendigo, ser o que sou, e nāo parecer.

Pode-se dizer que a técnica mimética não só abdica da natureza, mas também a vence. A qualidade da representação reside na eficiência dos próprios mecanismos representativos (técnica mimética), não na qualidade do ser real (natureza) que deveria servir de base para a representação ${ }^{15}$. Eurípides, manuseador da técnica mimética, é experto nos "mecanismos" da mimese (Thesm. 927, 1132: mekhanen $^{16}$; cf. Ach. 391), isto é, nos artifícios do discurso com que constrói suas tragédias, como "frases feitas" (cf. Ach. 444, 447: rhematiois) e "versos prontos" (Ran. 942: epylliois).

Tão importante quanto os artifícios do discurso é a atenção às leis intrínsecas do discurso, as leis da verossimilhança, que garantem a boa manipulação daqueles. Essas leis, todavia, confundem-se com as leis da lógica. Daí defender Eurípides, no pnîgos do agón das Rãs, os "mecanismos da lógica" (Ran. 973: logismòn entheis tê tékhne; cf. Ran. 774-5: hoi d'akroómenoi tôn antilogiôn kal lygismôn kal strophôn). 
Em suma, a técnica mimética realiza o casamento das formas do discurso, ou estética, com as leis da verossimilhança, ou lógica ${ }^{17}$.

Do mesmo modo que a qualidade da representação reside na eficiência dos mecanismos representativos, não na qualidade do ser real que deveria ser representado, o sucesso do poeta ou orador depende exclusivamente do conhecerem-se e empregarem-se os artifícios do discurso (técnica mimética), e não de qualidades pessoais (natureza) que aqueles possam apresentar, tais como a sinceridade do poeta ou o caráter do orador. Assim, se, por um lado, a técnica mimética realiza o casamento da estética com a lógica, por outro, separa o discurso (técnica mimética) do caráter (natureza) de quem fala, isto é, separa a estética da ética ${ }^{18}$. A citação do Hipólito de Eurípides em Thesm. 275-6 propõe justamente a dissociação entre a palavra e a intenção de quem fala:

$$
\begin{aligned}
& \text { [...] hóti he phrèn ómosen, } \\
& \text { he glôtta d'ouk omómok' [...] } \\
& \text { O coraçāo prometeu, mas a língua não prometera. }
\end{aligned}
$$

A técnica mimética é lógica, mas aética. Assim, como bem se definiu, a qualidade da representação e a qualidade do poeta ou orador que emprega a técnica mimética são, não exatamente qualidade (natureza), isto é, virtude (ética), mas eficiência (técnica/lógica). Num passo do antepírrema do agón das $R \bar{a} s$, Eurípides demonstra estar interessado, não na virtude do indivíduo, mas na "eficiência" (Ran. 1009-11), designada com a palavra beltion (Ran. 1009).

Enfim, a técnica mimética afirma sua natureza técnica, por assim dizer. Ela não é, nesse sentido, uma ciência (epistéme), cujos princípios se fundamentam numa observação da natureza, mas uma técnica (tékhne), cujos mecanismos, e não princípios, se articulam quase automaticamente ${ }^{19}$. Assim, o verbo empregado por Eurípides no agón das Rãs para definir a arte que pratica é tekhnyázo (Ran. 957). $\mathrm{E}$ quando Diceópolis anuncia sua intenção de recorrer aos artifícios de Eurípides (Ach. 383-4), o coro dos Acarnenses nomeia a atitude daquele com o mesmo verbo tekhnyázo (Ach. 385).

\section{Poesia e natureza}

Mas Eurípides será o poeta perdedor do agón das $R \bar{a} s$ (Ran. 1469-73). A comédia aristofânica deixa entrever, com isso, que não é a poesia euripidiana o modelo estético que defende. Com um artifício sagaz, usa da citação do Hipólito de Eurípides em Thesm. 275-6, que tão bem definiu o caráter peculiar daquela poesia (cf. supra), para, com uma paródia da mesma citação, justificar a derrota do poeta no agón das $R \tilde{a} s$, mais precisamente, por que Dioniso, tendo dito que iria ao Hades buscar o poeta Eurípides, agora parte levando consigo outro poeta (Ran. 1469-73):

\section{He glôtt'ọmómok' (Ran. 1471)}

A língua prometera. 
A citação e a paródia da citação têm sentido inverso: naquela, enfatiza-se o poder do discurso (Thesm. 276: glôtta), a que se subordina a intenção (Thesm. 275: phrén) de quem fala; nesta, insinua-se justamente o contrário, isto $\hat{E}$, a supremacia da intençāo (cf. Ran. 1468: psykhé) em relação ao discurso (Ran. 1471: glôtt').

A comédia aristofânica discorda da autonomia técnica da poesia euripidiana em relação à natureza. Para esta, como vimos, as qualidades da poesia e do poeta significam não exatamente qualidade (natureza), isto $\hat{\epsilon}$, qualidade do objeto representado e qualidade pessoal do poeta, mas eficiência (técnica), isto é, funcionamento autônomo dos mecanismos do discurso e, para o poeta, conhecimento e aplicaçāo destes. A comédia aristofânica, por sua vez, ocupa-se fundamentalmente da natureza; importa-lhe a natureza do objeto a ser representado, bem como a natureza do poeta.

E fundamental para a comédia aristofânica o caráter ético da poesia, isto é, o conteúdo ético do objeto a ser representado e o compromisso ético do poeta com a representação.

Quanto ao objeto, este deve apresentar um conteúdo ético elevado. No prólogo das Vespas, após explicar aos espectadores o tema da comédia, Xântias avisa que não se deve esperar um tema muito elevado - este mais conviria a uma tragédia -, mas de modo algum um tema vulgar (Vesp. 56-7). Mais claramente, $€$ Diceópolis, cujas posiçōes coincidem com as de nosso autor (cf. $A$ ch. 502, 377-8 e 5-8), quem afirma, no discurso em trímetros da cena imediatamente anterior à parábasis dos Acamenses, que o objeto da comédia pode e deve ser o "justo" (Ach. $500-1)^{20}$. Na parábasis da mesma peça, reafirma esse ponto de vista o corifeu (Ach. $645,655)$.

Quanto ao poeta, este deve manter um compromisso ético com o discurso. Ainda nos Acarnenses, Dicé́polis declara, sempre em nome do Poeta, que fala o que pensa (Ach. 369). Insiste-se na conciliação da palavra com o caráter daquele que a profere: em dois passos quase idênticos, na parábasis das Vespas (1036-7) e na parábasis da Paz (759-60), anuncia o corifeu que o Poeta diz sempre o que pensa, ainda quando ameaçado por pressōes políticas (cf. Vesp. 1284-91).

Somente após fundamentar-se na natureza, a comédia aristofânica irá construir seu discurso, de modo que este seja decorrência imediata do conteúdo ético. Assim, declara o corifeu da $\mathrm{Paz}$, na parábasis da peça, que a comédia aristofânica, uma "arte elevada" (Pac. 749: tékhnen megálen), tem "palavras e pensamentos elevados" (Pac. 750: épesin megálois kai dianoíais).

Do mesmo modo, as personagens devem ser personagens nobres. Assim, afirma o corifeu, na parábasis das Vespas, que o Poeta não põe em cena homens comuns (Vesp. 1029). Uma personagem de caráter nobre, contudo, dificilmente sobreviveria numa comédia; a solução de Aristófanes, então, é pôr em cena homens comuns mas perigosos (cf. Vesp. 1029-42; Pac. 751-8), com dentes pontiagudos e olhares terríveis (Vesp. 1030-2; Pac. 754-5), semelhantes a Lamias (Vesp. 1035; Pac. 758) e outros monstros (Vesp. 1038), e que exijam oponentes a altura, homens extremamente corajosos, de uma coragem hercúlea (Vesp. 1030; Pac. 752).

$\mathrm{Na}$ verdade, trata-se de atençăo à verossimilhança (cf. Vesp. 1027: epieikê): para um conteúdo de valor ético elevado, um estilo elevado; para proferir um discurso de estilo elevado, uma personagem de caráter. Porém, é importante observar que, diferente da poesia euripidiana, em que as leis da verossimilhança constituem um mecanismo auto-suficiente, a comédia aristofânica dota as mesmas de conteŕdo ético. 
Assim, a comédia aristofânica difere da poesia euripidiana não por não empregar os mecanismos lógicos que esta emprega, mas por dotá-los de conteúdo ético, ou, simplesmente, por dotá-los de sentido. Já o caráter auto-suficiente que os mesmos apresentam na poesia euripidiana produz um discurso vazio. $O$ termo pejorativo empregado por Aristófanes para designar a vacuidade desse discurso é laléo, "tagarelar". Isso diz Eurípides, no agón das Rãs, ter ensinado aos homens (Ran. 954), o que confirma, no mesmo agón, Esquilo (Ran. 1069; cf. 916-7). E tagarelice também o que Eurípides espera da personagem feminina que criou no prologo das Mulheres que celebram as Tesmoforias (cf. Thesm. 267).

Poder-se-ia dizer que, ao transformar a comédia aristofânica o caráter puramente lógico das leis da verossimilhança, seu estilo e suas personagens passam a ser, em vez de uma conseqüência lógica (técnica), uma decorrência natural (natureza) do conteúdo ético. A forma daquela comédia nāo é representação da representaçāo da natureza, mas, fundamentada na natureza e, mais que isso, penetrada pela natureza, pretende ser apresentação da natureza. Em outras palavras, a comédia aristofânica repudia o efeito ilusório da técnica mimética ${ }^{21}$. Assim, na parábasis dos Acarnenses, o corifeu declara que o Poeta não quer "iludir" os espectadores (Ach. 657: exapatýllon).

Em função do ponto de vista que defende, a comédia aristofânica critica a poesia euripidiana. O caráter técnico da poesia euripidiana não passa, para aquela, de tecnicismo, uma vez que é fruto de mecanismos do discurso, que funcionam de maneira autônoma (clichês), e, conseqüentemente, vazia de conteúdo ético. Assim, o prólogo das $R a \tilde{s}$ abre-se com uma divertida paródia dos clichês da comédia (Ran. 1-18). Já no início da cena dos trímetros entre a primeira e a segunda parábasis das Aves (903-58), parodiam-se os lugares-comuns das poesias Épica (Au. 907-10) e lírica ( $A u .950)$, de que tanto se mostra conhecedora a personagem do poeta. E no prólogo das Mulheres que celebram as Tesmofórias, parodiam-se os clichês do coro trágico, numa espécie de parakhorégema (Thesm. $101-29)^{22}$.

A poesia euripidiana, por ser representação da representação (técnica), pode dizer-se artificial, isto é, sem conteudo real (natureza); por outro lado, devido a seu caráter tecnicista, pode dizer-se artificiosa, isto é, cheia de fórmulas. Ora, a artificialidade dos artifícios teatrais de Eurípides é bem demonstrada em passos que parodiam a técnica composicional do poeta. O passo de $A c h$. 431-79, a que se assemelha o de Thesm. 213-63 e em que Diceópolis vai arrancando a Eurípides, um a um, os aparatos indumentários das personagens coxas deste, até que Eurípides exclame que nada lhe restará de sua tragédia (Ach. 464, 470), demonstra que, suprimidos os artifícios, nada fica da poesia euripidiana e que, conseqüentemente, esta é artificial.

E não só artificiais, mas até supérfluos são os artifícios da poesia euripidiana. E o que se depreende do passo em que, ao tomar Dicé́polis mais um dos aparatos indumentários de Eurípides, o cestinho queimado, e ao perguntar o tragediógrafo àquele a razão de querer tal peça, Diceópolis diz que justamente não há razão alguma (Ach. 454-5)... No passo anteriormente citado das Aves, aponta-se, de maneira mordaz, o supérfluo dos lugares-comuns da épica e da lírica: o poeta das Aves já compusera um canto para a Nefelocucolândia antes mesmo de esta ter sido fundada (Au. 920-3)...

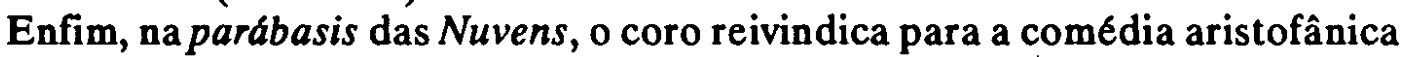
a qualidade de, diferente das demais comédias, evitar os lugares-comuns ( $N u b$. 
537-59). Isso a comédia aristofânica reafirma em diversos passos (cf. Pac. 741-50; Plut. 796-9).

\section{A poesia e o duelo de técnica e natureza}

E fácil notar. De um lado, Eurípides, com uma poesia trágica cujo tema é desavisadamente vulgar; de outro, Aristófanes, com uma poesia cômica cujo tema é inesperadamente elevado. Trata-se de uma simplificação cômica: de uma antítese simplista, a comédia aristofânica produz o burlesco. Mas é Esquilo que, poeta trágico como Eurípides, irá opor-se mais imediatamente a este.

A poesia esquilina opõe-se à poesia euripidiana tal como o fez a comédia aristofânica, isto é, fundamentando-se na natureza. Em primeiro lugar, observa o conteúdo ético do objeto a ser representado. Assim, diz Esquilo que a poesia deve eleger o que é "honesto" (Ran. 1056: khrestá) e rejeitar o que é "vil" (Ran. 1053: ponerón). Em segundo lugar, constrói a forma poética como decorrência natural daquele conteúdo, isto $\epsilon$, observa as leis da verossimilhança, mas preenche-as com a qualidade natural do objeto representado. Assim, diz Esquilo que, pela "lei da verossimilhança" (Ran. 1060: eikós), seu estilo é elevado porque seu pensamento é elevado (Ran. 1058-61: megálon gnomôn kai dianoiôn isa kaì tà rhémata tíktein) - Esquilo sabe que legou à poesia dramática, não o estilo mais elegante, como o de Eurípides, mas o "mais honesto" (Ran. 1062: khrestôs, 1060: khrêsthai; cf. supra nota 6) - e, conseqüentemente, as personagens que proferem o discurso devem ser personagens nobres: semi-deuses (Ran. 1060) e corajosos her6is, como Pátroclo e Teucro (Ran. 1042), mas principalmente como Aquiles, a que tantas vezes se associa a figura do próprio Ésquilo (cf. Ran. 992-3, 1264; cf. 832) e que, como personagem dos Frígios deste, tanto apraz a Eurípides criticar (Ran. 912).

A oposição entre a poesia esquilina, fundamentada na natureza, e a poesia euripidiana, articuladora da técnica mimética, desenvolve-se nas $R a \tilde{s}$, ao longo do agón desta e das demais cenas, até o êxodo.

Como vimos, Eurípides acusa o estilo esquilino de alertar a percepção metalingǘstica do espectador e, conseqüentemente, não produzir o efeito de realismo, isto é, fazer o espectador sentir que está diante, não de um discurso poético (técnica mimética), mas de um discurso informal (natureza).

Já Ésquilo acusa a poesia euripidiana de vulgaridade. Em primeiro lugar, vulgaridade do tema, pois o tema predileto desta é o adultério (Ran. 1043-4, 1050-1); em segundo lugar, vulgaridade da forma, que apresenta estilo e personagens degradadas (Ran. 1062-3).

Assim, os poetas acusam-se mutuamente. Mas é necessário cuidado. Um e outro poeta observam diferentes princípios composicionais, e as críticas de um e outro fundamentam-se em pontos de vista diferentes. Eurípides pensa a poesia como representação da representação, a que basta a articulação autônoma dos mecanismos do discurso para produzir o efeito de realismo, a ilusão poética. Por isso critica fundamentalmente, na poesia esquilina, o estilo e a incapacidade deste de produzir a ilusão poética.

Esquilo considera a poesia ancorada na natureza e penetrada por esta, quer dizer, observa a natureza do objeto a ser representado e o compromisso do poeta com a representação poética e, a partir dessa observação, constrói uma forma 
poética que os reflita da maneira mais imediata. Por isso critica basicamente, na poesia euripidiana, os temas, isto é, o conteúdo imoral daquela poesia, bem como a falta de qualidade ética do estilo e das personagens euripidianas.

Assim, é necessario reconsiderarem-se as acusaçōes de cada poeta. Eurípides, ao acusar fundamentalmente o estilo da poesia esquilina, não percebe que este é decorrência natural do conteúdo ético do objeto representado. Do mesmo modo, não percebe, ao apontar a falta de realismo da poesia esquilina, que esta se preocupa, não com o efeito de realismo (técnica), mas com a própria realidade (natureza) do objeto a ser representado. Assim, a poesia esquilina, por não produzir o efeito de realismo como quer Eurípides, não deve ser acusada de anti-realista; ela é simplesmente uma poesia da natureza.

Esquilo, ao acusar fundamentalmente os temas da poesia euripidiana, não percebe que eles são apenas conseqüência lógica da técnica mimética, isto é, o conteúdo da poesia euripidiana é escolhido, não em função de uma predileção de Eurípides por temas vulgares (natureza), mas simplesmente pela aptidão do tema para produzir o efeito de realismo (técnica). Assim, a poesia euripidiana, por não apresentar um tema de alto valor ético, não deve ser acusada de anti-ética; ela é simplesmente uma poesia técnica.

Cada poesia tem as suas propriedades. A poesia euripidiana caracteriza-se por ser ela mesma uma aparência, isto é, representação da representação, mas também por fazer-se parecer realidade aos olhos do espectador. Assim, Eurípides, ao pretender que o espectador se sinta diante da realidade, na verdade o ilude.

A poesia esquilina preocupa-se com a natureza do objeto a ser representado e, por isso, faz um recorte na realidade, isto é, seleciona o que desta deva ser representado ou nāo. Por sua vez, essa seleção é feita em função do compromisso ético que o poeta deve manter com a representação poética, isto é, seleciona-se o objeto que o poeta julgue o mais elevado. Feito isso, constrói-se a forma poética - o estilo e as personagens - penetrando-a de todo o valor ético que possua o objeto representado e que importe ao poeta. Assim, Esquilo, embora apresente ao espectador um recorte da realidade, fá-lo de maneira viva, isto é, o espectador, embora se perceba diante de uma ficção poética, é penetrado pelo conteúdo real do objeto e pelo sentimento real do poeta.

Em suma, a poesia euripidiana, representação da representação, aparenta (e nāo é) realidade; a poesia esquilina, apresentação do ideal, é (e não aparenta) idealidade. Plagiando e adaptando a expressāo aristotélica (Poet. XXV 1661460 b 31-5), pode-se dizer que, de um lado, as personagens euripidianas representam os homens tais como são, enquanto as esquilinas apresentam os homens tais como deveriam ser; ou ainda, as personagens euripidianas aparentam homens reais, as personagens esquilinas săo homens ideais.

\section{Notas}

1- Cf. o fragmento heraclitiano: He tékhne tèn phỳsin mimouméne (Herácl. B 10). 2- Na verdade, o adjetivo kompsós associa-se intimamente ao estilo euripidiano (cf. Equ. 18: kompseuripikôs). Assim, Terâmeno, um admirador de Eurípides, tambem é "elegante" (Ran. 967). Também o hábil discurso da segunda personagem 
feminina das Mulheres que celebram as Tesmofórias é qualificado pelo coro como "elegante" (Thesm. 460).

3- Sobre a dissimulatio artis, cf. ARSTT. Rhet. III 21404 b 18-21: Did dế lanthánein poiountas, kal mè dokeîn légein peplasménos alld pephykótos (toato gdr pithanón, ekeîno dè tounantion, hos gàr pros epibouleúonta diabállontai, katháper pros toùs oinous toùs memigménous).

4- Diz Aristóteles (Rhet. III 21404 b 24-5) que foi Eurípides o primeiro a recorrer a linguagem coloquial para produzir a dissimulatio artis (cf. nota anterior).

5- Sobre os prólogos explicativos das tragédias de Eurípides, cf. ARSTT. Rhet. III 141415 a $19-20$.

6- O verso é proferido por Dioniso após terem Eurípides e Esquilo exposto os pareceres próprios a respeito de Alcibíades (Ran. 1422): a opiniāo daquele é taxativa (Ran. 1427-9) - como convém à clareza do estilo euripidiano -, a deste, metafórica (Ran. 1431-2) - como convém à nobreza do estilo esquilino (cf. Ran. 1062).

7- A clareza é, para Aristóteles (Rhet. III 21404 b 1 ss.), a primeira qualidade da expressão (léxeos areté saphê), e associa-se diretamente a Eurípides (id. 24-5).

8- Ao tratar da clareza do discurso e da dissimulatio artis (cf. supra notas 3 e 6), Aristóteles privilegia o discurso que imita a linguagem coloquial, e não poética (Rhet. III 21404 b 3-24), e associa essa técnica a Eurípides (id. 24-5).

9- O próprio Eurípides é filho de uma vendedora de legumes (Thesm. 387; cf. Thesm. 456; Ach. 478), personagem típica da ágora. Do mesmo modo, é justamente uma vendedora da ágora (Thesm. 457) que vence o agón das Mulheres que celebram as Tesmoforias (Thesm. 459-61). O nome da bem-falante personagem feminina da Assembléia das mulheres, Praxágora, associa a técnica oratória desta à maneira de falar dos comerciantes.

10- Também pela lei da verossimilhança, o estilo esquilino exige caracteres afins, o que bem demonstra saber o próprio Esquilo (cf. Ran. 1058-61).

11- Dirá Aristóteles que o discurso deve "ocultar a sua construçāo retórica" (Rhet. III 21404 b 18: lanthánein poioantas) a fim de ser "persuasivo" (id. 19: pithanón; cf. supra nota 3).

12- Praxágora, que constrói oradores por meio da elaboração do discurso, também busca a persuasão do ouvinte (Eccl. 209, 239).

13- A ousada solução euripidiana de elaborar um estilo e uma personagem dramática diferentes dos convencionais é parodiada, com grande humor, em Ran. 1331-63, em que se apresenta uma situação cheia de elementos trágicos: o sonho da personagem (Ran. 1332), a interpelação de divindades (Ran. 1335, 1345, 1361-2), o rito de purificação (Ran. 1338-40), e tudo por causa do roubo de um galo...

14- Faz-se uma paródia do sentimento produzido pelo discurso poético no espectador em Thesm. 130-3, em que se descrevem os sentimentos lascivos produzidos pelo canto sedutor de Agatão no parente torto de Eurípides.

15- Cf. ARSTT. Poet. XXV 1621460 b 13-9.

16- Os filhos dançarinos de Carcino, mencionados em Pac. 781-4, são designados mekhanodiphai (Pac. 790; cf. Pac. 864), isto é, dançarinos tecnicistas, malabaristas. Em Vesp. 1474-537, faz-se uma longa paródia da dança moderna de Frínico. $O$. fato de ser Filocleo bêbado quem vai dançar a Frínico já indica que a dança deste não passa de uma série de tropeços (Vesp. 1484-6), na verdade, uma dança malabarística (Vesp. 1523-5), que movimenta a coluna vertebral (Vesp. 1498-9), as pernas 
(Vesp. 1491), as articulações (Vesp. 1494), o fêmur (Vesp. 1495), mas tudo só para causar sensação no espectador (Vesp. 1525-6), para persuadi-lo, por assim dizer. 17- A relação entre retórica e dialética é o que primeiro se afirma na Retórica aristotélica: He rhetoriké estin antistrophos tê dialektikê (I 11354 a 1; cf. id. 1355 b 8-21; 21356 a 25-33).

18- Cf. ARSTT. Rhet. I 21356 a 20-5.

19- Segundo Aristóteles, a retórica não pertence a nenhuma "ciência" (Rhet. I 1 1354 a 3: Oudemiás epistémes aphorisménes; cf. id. 21356 a 32), mas é propria de uma "técnica, ou arte" (id. 11: Tékhnes érgon eînai).

20- Assim como o nome de Praxágora revela o tipo de discurso que a personagem feminina conhece (cf. supra nota 9), assim o nome de Diceópolis revela o tipo de objeto de que esta personagem se ocupa.

21- Da mesma forma, aquela comédia deprecia o efeito persuasivo da técnica mimética (cf. Ran. 1396).

22. Ao mesmo tempo, parodiam-se as inovaçōes das formas poéticas. No agón das Rãs, parodiam-se, na voz de Ésquilo, as inovaçōes musicais de Eurípides (Ran. 1309-22), seja suas inovaçōes melódicas (cf. Ran. 1314, 1347) seja suas inovaçōes rítmicas (cf. Ran. 1322-3). É que a técnica poética euripidiana, por ser apenas um jogo tecnicista, só pode usar de fórmulas, seja porque usou de fórmulas previamente conhecidas seja porque tudo o que possa criar se transforma em fórmula.

SANTOS, M. M. La théorie littéraire aristophanique. Classica, São Paulo, 5/6: 79-91, 1992/1993.

RESUME: Outre les thèmes sociaux et politiques, la comédle aristophanique présente le thème littéraire. Celul-ci se déroule, de façon sporadique, dans une scène des Acharniens (407-78) et, de façon inconditionelle, aux Thesmophories - particulièrement dans la scène jouée par Agathon (Thesm. 97-265) - et dans la deuxlème partie des Grenouilles (738-1533). On peut dire que la comédie aristophanique élabore un système de critique littéraire, dans lequel on peut discerner deux types fondamentaux de poésle: la poésie qui imite la poésie même (tékhne), dont Euripide est le modèle, et la poésie qui imite la nature (physis), dont Eschyle est le modèle. MOTS CLES: Aristophane, théorie littéraire, théâtre. 